\title{
Training Systems and Labor Mobility: A Comparison between Germany and Sweden*
}

\author{
Tomas Korpi
}

Stockholm University, SE-106 91 Stockholm, Sweden

tomas.korpi@sofi.su.se

\section{Antje Mertens}

Max Planck Institute for Human Development, D-14195 Berlin, Germany

mertens@mpib-berlin.mpg.de

\begin{abstract}
The mobility effect of general and specific training is a key issue in the debate on the design of educational systems. Using data from two retrospective life-history surveys, we compare general school-based vocational training and specific apprenticeship training with regard to inter-firm, inter-occupational and inter-industrial mobility. The results show that workers with school-based degrees display greater occupational mobility, while no difference in firm and industrial mobility can be discerned. This suggests that apprenticeships do not eliminate job search at labor market entry, that they reduce occupational mobility, and that responsiveness to structural change is similar under both training systems.
\end{abstract}

Keywords: Vocational training; apprenticeship; labor mobility

JEL classification: $I 28 ; J 62 ; J 68$

\section{Introduction}

It is well known that the amount of schooling and vocational training received by young workers is related to income and employment during working life. There is less agreement, however, regarding the effects of how such training is acquired. In particular, there is an intense policy debate as to whether or not vocational training should be offered within the general educational system and, if so, how it should be organized.

\footnotetext{
* We would like to thank Michael Burda, Karl-Ulrich Mayer, Lena Granqvist, Helena Persson, Markus Pannenberg, Hielke Buddelmeyer, Harald Uhlig, Axel Werwatz and two anonymous referees, as well as seminar participants in Berlin, Helsinki, Mannheim and at the EEA 2001 meeting for comments and discussion.
} 
Central to this debate is the question of mobility. Are individuals with firm-based vocational training more or less mobile than those who receive their vocational training in schools? From a macroeconomic standpoint, it is often argued that the continuous contraction and simultaneous expansion of different industries, occupations and firms require a mobility-facilitating training system; see e.g. Thurow (1992). Mobility may also be an important means for workers to improve their own economic position; see e.g. Topel and Ward (1992). However, excessive mobility is often regarded as destructive for the individual, in particular during the early stages of a career. Too frequent job switches and interruption through unemployment spells may lead to loss of human capital and become a signal of limited employability, resulting in an eventual decrease in earnings potential; see e.g. Spence (1973) and Stern, Finkelstein, Stone, Latting and Dornsife (1995). In addition, job hopping may be undesirable for the economy as a whole if economic success depends on long-term labor relationships; see Baily, Burtless and Litan (1993). Against this background, it is especially important to understand the ways in which vocational training systems influence mobility in the labor market. This would indeed constitute a prerequisite for educational reform.

In principle, there are two alternative ways of supplying the labor market with trained workers. The first would be to rely solely on firms to provide inhouse training, while the second would be to organize vocational training as school-based training, devoid of any firm-specific content. In practice, vocational training in most countries takes place somewhere in-between these two extremes. The US and Japan are probably the industrialized countries which correspond most closely to the first model, in that little training is provided within the general educational system.

The school-based alternative is most extensive in some European countries, notably Finland, France, Norway and Sweden. Here, vocational skills are taught in a classroom setting and substantial weight is also given to general education. Workplace experience is limited to brief spells of firmbased training. The training systems of some other European countries rank somewhere in-between. They also exhibit a substantial degree of firmrelated training, although provided within the general educational system in the form of apprenticeship training supplemented with some general education. Compared to the school-based systems, the emphasis here is reversed, with less weight given to general education. This type of system is frequently identified with the dual system in Germany, but is also found in the other German-speaking countries as well as in Denmark and the Netherlands.

Several arguments suggest that school-based training should be associated with greater mobility than firm-based training. Apprenticeship systems are 
often believed to facilitate labor market entry in the sense that direct employer contacts and a higher proportion of firm- and occupation-specific training may reduce job search. Furthermore, although apprenticeship systems in Continental Europe are intended to deliver transferable occupational skills, on-the-job training will by necessity contain elements very specific to a particular job and firm. This may imply that a greater proportion of schoolbased training is transferable between different jobs, firms and employers. Moreover, the provision of apprenticeship training is not costless to firms. To meet these costs, firms are often believed to strive for a long-term employment relationship that extends beyond the training period. However, recent research on mobility among apprenticeship-trained workers in Germany suggests that the links between vocational training and mobility are less straightforward. Mobility after completion of an apprenticeship is relatively high, between both firms and occupations; see Winkelmann (1996a,b), Harhoff and Kane (1997) and Franz and Zimmermann (1999). Hence, it has been suggested that a non-negligible percentage of training is general. If this is the case, it becomes much less certain that the mobility outcomes of an apprenticeship system differ from those where vocational training is supplied in schools rather than in firms.

Two issues therefore call for further investigation. Does an apprenticeship system really reduce mobility and, if it does, what kind of mobility? The purpose of this paper is to examine firm, occupational and industrial mobility among German apprentices and Swedish vocational students. The outline of the paper is as follows. In Sections II and III we describe the vocational education systems in greater detail and review the theoretical and empirical literature. In Section IV we consider the effect of training on mobility using hazard models and two comparable retrospective life-history datasets from Germany and Sweden. In both datasets, individuals who enter the labor market between the early 1970s and the mid-1980s are observed up until the early 1990s. Section V concludes.

\section{Two Systems of Vocational Education}

The basis for this paper concerns the similarities and differences in the way vocational training at the upper secondary level is provided in Germany and Sweden. The key aspects are the general structure of the programs and the relative weight of workplace training in the two systems.

The core of the German system of vocational training is the apprenticeship system. The starting age of an apprenticeship is between 16 and 19 years, depending on which track was followed in school. In the period studied here, around $50 \%$ of German youths aged 16-19 took part in the 
apprenticeship system; see Schober-Brinkmann and Wadensjö (1991). ${ }^{1}$ Basically all sectors of the economy offer training. Today, there are roughly 360 different nationally recognized apprenticeship programs, which usually last 2-3.5 years depending on the occupation. To ensure the quality of the training and the transferability of qualifications, there are legal requirements on the minimum amount of material that has to be covered. The curricula are developed in close cooperation between employers' associations, trade unions and government institutions such as the Federal Institute for Vocational Training (Bundesinstitut für Berufsbildung, BiBB). The system is often referred to as the "dual system of vocational training" as trainees receive school education at public vocational schools (Berufsschule) 1-2 days per week and on-the-job training within firms 3-4 days per week.

The Swedish system of vocational training was reformed in the early 1970 s, when vocational training was integrated into upper secondary education, and again in the 1990s. Here we focus on the situation in the 1970s and 1980s since this is the period covered by our data. Most students then entered the programs between the ages of 16 and 17. The proportion of 16-18-year-olds receiving vocational training in upper secondary school increased slowly during the period studied here, starting from $33 \%$ in 1975 and rising to $43 \%$ in 1985; cf. Statistics Sweden (1988). The system was characterized by having around 25 nationally recognized programs, subdivided into a total of approximately 60 certificates. ${ }^{2}$ While these programs attracted the majority of vocational students, there were also a number of more specialized courses. The right to change, add and eliminate programs resided with the national government, as did decisions regarding the curricula. Decisions were preceded by extensive reviews; both employer organizations and trade unions were involved and represented on various committees dealing with issues related to curricula, etc. The duration of training was generally two years, and most training took place in school. The time spent in a workplace varied substantially, but a rough estimate based on survey results is that an average of one afternoon a week was allotted to firm-based training; cf. SOU (1986).

The German system thus differs from the Swedish program in that it offers more specific training, i.e., more disaggregated and specialized vocational

\footnotetext{
${ }^{1}$ For more detailed information in English, see e.g. Steedman (1993) or Wagner (1999). Fulltime vocational schools (e.g. Berufsfachschule) also exist, but are of minor importance in comparison with the dual system. In addition, training is only offered in a limited number of specific occupations, e.g. nursing.

${ }^{2}$ Both traditional apprenticeships, where all training takes place within the firm, and dual system apprenticeships existed in Sweden, but were extremely limited. This holds in particular for apprenticeships of the German type, which seem mainly to have existed on paper. Traditional apprenticeships were basically limited to a few craft occupations.
}

(C) The editors of the Scandinavian Journal of Economics 2003. 
training as well as more firm-specific training and earlier work experience. Even though the dual system offers a substantial amount of general training, German apprentices would still be expected to accumulate more firm- and occupation-specific skills than Swedish vocational trainees; cf. Acemoglu and Pischke (1999a, p. F124). While the German system may be more sensitive to employers' needs, the supply of apprenticeships may be less flexible than the supply of school-based vocational training slots. Nationally set curricula also ensure that the quality of training should be fairly similar within both countries. ${ }^{3}$ In addition, since the apprenticeship system in Germany and the system of school-based vocational training in Sweden are the standard routes to vocational qualifications in the two countries, both groups could be expected to be relatively similar.

\section{Vocational Training Systems and Labor Mobility}

There has been relatively little theoretical work on the effects of different types of vocational training on mobility. Most models of training instead focus on the provision and financing of firm-specific and general training, and the consequences thereof for earnings possibilities and worker/firm separations. Nevertheless, these theories yield some indirect hypotheses about the relationship between type of training and subsequent mobility.

In his seminal work Becker (1964) argued that a firm in a competitive market will not pay for general training of its workers because this would raise the workers' productivity in other firms. Firms which finance such training could lose their workers to competitors who do not provide training and therefore are able to offer higher wages. In contrast, the standard analysis of investments in firm-specific human capital argues that such investments are shared by the worker and the firm; see e.g. Becker (1964) and Hashimoto (1981). Employers may be willing to co-finance firmspecific human capital acquisition among their workers because marginal products outside the firm are not influenced by this investment. As long as workers receive some return on their specific investment, the probability of quitting will be reduced. Furthermore, the firm is more likely to avoid layoffs in a downturn, as it may otherwise incur considerable training

\footnotetext{
${ }^{3}$ While monitoring of public training schemes as in Sweden might be difficult, the quality of training in Germany has also been questioned; see Steedman (1993). Apprentices in the crafts sector frequently perform regular work whereas those in the industrial sector tend to receive training throughout their apprenticeship. Moreover, firms often train in training shops, rather than directly at the workplace.
} 
costs when the economy recovers. From this basic model it follows that labor mobility should be lower in the presence of firm-specific human capital. It therefore seems likely that the type of vocational training would influence subsequent mobility.

Non-competitive theories of training also suggest that market imperfections may lead to firm-financed general training; see Acemoglu and Pischke (1999a) for an overview. This, in turn, may influence mobility. Stevens (1994) thus proposed a model where skills are neither completely general nor purely specific, so that firms may finance the acquisition of skills that are partly general. Similarly, Franz and Soskice (1995) argued that general and specific human capital are complements in training. When firms' production technology requires some firm-specific components, such complementarity may make it less costly to train apprentices than to hire external workers. Firms cannot reap the benefits of such general training unless they are able to limit poaching by other firms. It has been suggested that German works councils and trade unions act as a necessary mobility constraint (Soskice, 1994). ${ }^{4}$

A further aspect is the "adverse selection" story developed by Acemoglu and Pischke (1998). Firms may provide their workers with general training because, relative to other firms, they have superior information about worker ability. Following training some workers quit and others are laid off, yet outside firms do not observe the reason for separation or worker ability. If most separations are due to lay-offs then the pool of workers available to outside firms may be of poor ability. Outside firms will then offer relatively low wages, thereby limiting the workers' possible gains from mobility. ${ }^{5}$ These models thus suggest that any general training received in the course of firm-based training will be associated with reduced mobility.

This theoretical literature focuses on the distinction between specific and general training, with little concern for possible differences in specificity. Although specific training is often implicitly equated with a firm-specific component, in our view industry- and occupation-specific human capital investments are also of importance. For example, a worker in the primary sector (e.g. forestry or mining) may be able to move from one firm to another within the industry, yet have difficulties moving to the service

\footnotetext{
${ }^{4}$ Harhoff and Kane (1997) proposed an argument based on unobserved heterogeneity in worker costs of mobility. They found evidence that apprentices who stay with their training firm earn less than those who leave; see also Acemoglu and Pischke (1998). Conflicting results have also been found; see Euwals and Winkelmann (2001).

${ }^{5}$ Other market imperfections leading to firm-financed training of general skills include the presence of transaction costs, as in Acemoglu (1997), asymmetric information between worker and employer regarding worker effort, union wage setting, as in Acemoglu and Pischke (1999b), and efficiency wages, as in Loewenstein and Spletzer (1999).
}

(C) The editors of the Scandinavian Journal of Economics 2003. 
sector. Industry-specific skills increase productivity in more than one firm, but not in every industry. ${ }^{6}$ Similarly, occupation-specific skills increase productivity in several firms but not in different occupations. Thus, investments in these types of specific human capital could also be expected to reduce mobility.

Turning to the empirical literature, there are two issues of relevance to this paper: the type of training provided within the apprenticeship system and the impact of type of training on subsequent careers. As regards the former, there is relatively little direct evidence on the type of human capital acquired during training periods. According to Franz and Soskice (1995), the fact that firms invest in apprenticeship training speaks in favor of (at least some) firm-specific training, as it is more costly to teach company-specific skills to externally hired workers. Winkelmann (1996b) notes that there is likely to be both some firm-specific and general human capital.

Lacking direct evidence, an indirect strategy for examining mobility (and sometimes wage) effects is commonly used to makes inferences about the type of training. Winkelmann (1996a) reported that $13 \%$ of those who complete an apprenticeship immediately enter an unemployment spell. But those with university or post-secondary full-time school training experienced higher rates of post-training unemployment incidence. Winkelmann (1996a) referred to two possible explanations for apprenticeship graduates' smoother transition to work. First, their early attachment to the labor force may provide workplace experience that promotes efficient search. Second, search is not an issue for a large percentage of young workers at all, as $69 \%$ stay with their training firm after an apprenticeship. Similar results were reported by Booth and Satchell (1995) for the UK. They studied young workers in the 1970s and found that completed apprenticeships significantly reduce the (voluntary and involuntary) exit rates from a job. As they argued, this indicates that both employers and youths who have completed apprenticeships wish to continue the employment relationship.

However, Franz and Zimmermann (1999) reported that $50 \%$ of all young workers leave their training firm within the first two years, and only $30 \%$ remain with their firm five years after an apprenticeship; see also Winkelmann (1996a). Harhoff and Kane (1997) found basically the same average retention rate of $30 \%$ after five years, but reported higher retention rates for workers in large firms. Moreover, they showed that this is a long-term phenomenon (since the 1950s). These findings seem to indicate that

\footnotetext{
${ }^{6}$ Most empirical studies also focus on firm switches; see for instance Topel and Ward (1992) and Farber (1994). Occupation and industry-specific skills are examined in e.g. Neal (1995), Winkelmann (1996b), Mertens (1998) and Burda and Mertens (2001).
} 
firm-specific human capital is of less importance than casually assumed, and that workers are indeed equipped with portable skills.

Still other studies have shown that there is some occupational mobility, although less occupation than job mobility; see e.g. Werwatz (1997). Hofbauer and Nagel (1987) reported that $40 \%$ leave their training occupation, as measured by the two-digit occupational code, within 5.5 years. ${ }^{7}$ As far as industrial mobility is concerned, Winkelmann (1996b) found that vocational training tends to be associated with less mobility than primary and secondary general education. It is unclear, however, whether there are any differences among various types of training.

To summarize, the theoretical work suggests that apprenticeship training should be associated with less mobility than school-based training. Nevertheless, empirical studies tend to find that although a large number of trainees remain with their training firm, there is also substantial mobility after apprenticeships. It is also worth noting that most empirical studies have focused on shifts between firms. There has been less interest in occupational and industrial mobility, although this is of direct relevance for the policy discussion.

\section{Labor Market Mobility in Germany and Sweden}

\section{Data}

Our German data are from the German Life History Study (GLHS), while the Swedish data are from the Swedish Level of Living Survey (LLS). The GLHS contains information on representative samples of different German birth cohorts. The analyses here were based on the cohorts born during 1954-1956 and 1959-1961, interviewed in 1989, who entered the labor market roughly between 1968 and 1975; see Brückner and Mayer (1998). The sample size is around 2,000 men and women. The LLS is a survey among representative samples of the Swedish population, and the data used here pertain to the survey conducted in 1991; see Jonsson and Mills (2001). Owing to reforms in the Swedish educational system, described above, our analyses are also limited to those entering the labor market no earlier than 1975. Our sample consists of around 1,000 men and women, generally born between 1955 and 1965.

\footnotetext{
${ }^{7}$ This corresponds to findings for other countries with apprenticeship training such as the Netherlands where high rates of technically trained people work in non-technical occupations; see Borghans, de Grip and Smits (1995).
}

(C) The editors of the Scandinavian Journal of Economics 2003. 
These two surveys share many features. Of primary relevance here are the retrospective work histories contained in both surveys, including information on self-defined career episodes (jobs, unemployment, etc.) with a duration of at least one month. Owing to restrictions in the LLS, the work histories analyzed commence with the first job, with a duration of at least six months, after completion of the respondents' highest educational degree.

We have included all employees with valid observations on the variables of interest, with some exceptions. We have thus excluded the self-employed, as they could be expected to display very distinct mobility patterns and are of minor relevance for the training debate. ${ }^{8}$ We have also excluded German vocational school graduates, as full-time vocational schooling in Germany is relatively rare and very occupation specific, thereby raising issues of selfselection into different types of training. ${ }^{9}$

The overall structure of the work history information is thus very similar. This is also the case with the information used to create the three dependent variables: firm shifts, occupational shifts and shifts between industries. For each self-defined job in the work history, information was gathered as to whether this job was at the same workplace as the job immediately preceding it, the type of tasks performed, and the industry/type of production of the firm.

Using these data, our three measures of mobility can be defined as follows. First, inter-firm mobility is a job change involving a change of employer. Second, the information on tasks was used as the basis for occupational coding according to the International Standard Classification of Occupations 1968 (ISCO-68); inter-occupational mobility is then a change between three-digit ISCO. ${ }^{10}$ Third, the industry information was

\footnotetext{
${ }^{8}$ Some German civil servants (Beamten) have very strong mobility disincentives, such as guaranteed lifetime employment and exceptional health and pension benefits. Since they are likely to exhibit different mobility patterns, we experimented with excluding them. Our basic results, however, remained unchanged and this group has thus been included in the analysis. ${ }^{9}$ However, when these graduates were included in the analysis our major results did not change. Vocationally schooled and apprenticeship trained workers in Germany differ in that apprentices tend to be more mobile between occupations (results can be obtained from the authors on request). This is probably due to occupational segmentation where vocational school training is only offered for some select occupations.

${ }^{10}$ Hence, we measure occupational mobility between roughly 320 occupations. Note that workers may change occupations within the same firm in our dataset. The organizational structure of german firms matches the approximately 360 official training occupations; see Steedman, 1993, p. 1286). Since these occupations are strongly related to the ISCO definition, this procedure should yield a relatively good measure of occupational mobility. However, it is likely that we overestimate occupational mobility somewhat using the code-based measure. Werwatz (1997) shows, using another dataset for Germany, that subjective measures usually lead to lower rates of occupational switches than code-based measures. There is no reason to believe that the problem should be more severe in either country, however.
} 
recoded into 16 industries and inter-industrial mobility and then defined as a shift between two of these industries. ${ }^{11}$

Our educational indicators are elementary + secondary lower general, secondary vocational school, secondary vocational apprentice, secondary advanced general, tertiary (see Appendix, Table A1). Although primarily interested in effects associated with vocational training, we included the other groups as interesting comparisons. Given the general similarity in university education, any difference found in the effects of vocational education would appear less likely to be due to the content of the programs if differences are also found among those with university degrees. Any differences would then probably be associated with other factors.

\section{Model}

We examine duration data, i.e., the duration from entry into a firm, occupation or industry until entry into the next firm, occupation or industry, or right censoring at the time of an interview (note that periods not employed are included in the spell). The basic tools for modeling duration data are hazard functions $h(t)$ at some duration $t$. The hazard function $h(t)$ is the rate at which spells are completed after duration $t$, given that they last at least until $t$.

As individuals might face different risks of terminating a spell according to their environmental and individual characteristics and since the risk might change over the duration of a spell, the hazard function should be modeled such that it depends not only on time but also on covariates, i.e.:

$$
h(t)=\theta(t ; x) .
$$

We chose the popular semi-parametric proportional Cox model as a basis for our estimation. In this model, the effects of covariates on the hazard rate are restricted to be proportional, that is

$$
\theta(t ; x)=\theta_{0}(t) \exp \left(x^{\prime} \beta\right)
$$

\footnotetext{
${ }^{11}$ The shifts are between agriculture (including forestry and fisheries), energy and mining, chemicals, rubber and plastics, stone and glass, metals and engineering, wood/paper/printing, leather and textiles, food and tobacco, construction, trade (wholesale and retail), transportation and communication, banking and insurance, other services, private households, government and public administration.
}

(C) The editors of the Scandinavian Journal of Economics 2003. 
The major advantage of this model is that it leaves the form of the so-called "baseline hazard" $\theta_{0}(t)$ unspecified. Thus, no special assumption concerning duration dependence is necessary. ${ }^{12}$

We used the entire work history, i.e., we followed the respondents from labor-force entry up until the time of an interview. For many respondents we thus have multiple spells, and we controlled for the resulting non-independence of observations by estimating robust standard errors.

In the search for vocational-specific mobility effects, we used a simple step-by-step strategy. Starting with a model containing only the educational variables, we introduced other factors known to be related to mobility. We began with personal variables, and then extended the model by introducing firm, industry and business cycle indicators. ${ }^{13}$ To assume that the covariates have similar effects in the two countries, however, would seem a fairly strong restriction. ${ }^{14}$ Therefore the effects of these variables were allowed to be country specific. We thus modeled the hazard rate as

$$
\theta(t ; x)=\theta_{0}(t) \exp \left(x^{\prime} \beta_{j}\right),
$$

where $j=$ Germany, Sweden. The country-specific effects are modeled through the inclusion of interaction terms of all covariates with a dummy that equals 1 for all Swedish observations.

Despite the additional heterogeneity allowed for in this model, there may still be unobserved country-specific factors which affect the transition rate. This may bias the training effects to the extent that such unobserved heterogeneity is correlated with the educational indicators. In an attempt to account for this, we modeled country-specific baseline hazards which should pick up overall differences in mobility between the two countries. By allowing the baseline hazard to vary between the two countries, we thus model unobserved country-specific fixed effects not captured by the rest of the model. We then have

$$
\theta(t ; x)=\theta_{j 0}(t) \exp \left(x^{\prime} \beta_{j}\right)
$$

\footnotetext{
${ }^{12} \mathrm{We}$ also examined the importance of model selection by estimating Weibull and piecewise exponential models. One crucial difference between the Cox model and these other models is that none of them imposes the proportionality restriction. The results from these exercises were basically identical to those reported below. This was also the case when we experimented with taking unobserved individual heterogeneity into account by including a multiplicative gamma term. Results can be obtained from the authors on request.

${ }^{13}$ See the Appendix for definitions of independent variables and some descriptive statistics.

${ }^{14}$ See Di Prete, de Graaf, Luijlex, Tåhlin and Blossfeld (1997) for a discussion of mobility patterns in the two countries.
} 
In the final model we have thus taken a number of mobility-related factors into account, have allowed their effects to vary between the countries and have also allowed the overall rate of transition to be country specific.

\section{Results}

The importance of educational level for inter-firm mobility is examined in Table 1. Model I shows the simple relationship between attained level of education and the rate of transition between firms. The left-hand column shows the main effects, whereas the right-hand column contains the interaction terms. In our specification the main effects are those from Germany, while the interaction terms indicate the difference between the German and the Swedish effects. Starting with the results for Germany, there are clear differences in inter-firm mobility according to educational level. Those with vocational training and those with a university degree are less mobile than the reference group with no more than basic upper secondary education. The least mobile group, however, consists of those with an advanced upper secondary degree.

The results for the difference between the educational effects in Germany and Sweden show that each Swedish group has a higher rate of mobility than its German counterpart. Implicit in the table is also the result that the educational differences are less pronounced in Sweden than in Germany. The Swedish effects can be calculated by adding up the German effect and the Swedish difference, and vary between 0.018 and 0.172 . The estimated effects can also be expressed as transition probabilities; the estimates in Model I indicate that the likelihood of leaving a firm is $15 \%$ lower for vocationally trained German workers than for workers without training, whereas in Sweden it is $19 \%$ higher. Relative to their German counterparts, the likelihood of firm exit is $40 \%$ higher for the vocationally trained workers in Sweden. ${ }^{15}$

After adding indicators for personal, firm and business cycle factors, the educational effects between the countries are reduced. As can be seen from Model II in Table 1, the Swedish effects are slightly smaller but remain positive and significant for vocational and advanced upper secondary students. After the inclusion of industry dummies in Model III, the only remaining difference is between advanced secondary students. After allowing for unobserved country-specific fixed effects through the inclusion of separate baseline hazards in Model IV, the remaining educational difference is removed.

\footnotetext{
${ }^{15}$ The probabilities can be calculated as $\{\exp (-0.164)-1\}^{*} 100,\{\exp (0.336)-1\}^{*} 100$ and $\{\exp (-0.164+0.336)-1\}^{*} 100$, respectively.

(C) The editors of the Scandinavian Journal of Economics 2003.
} 
Training systems and labor mobility in Germany and Sweden 609

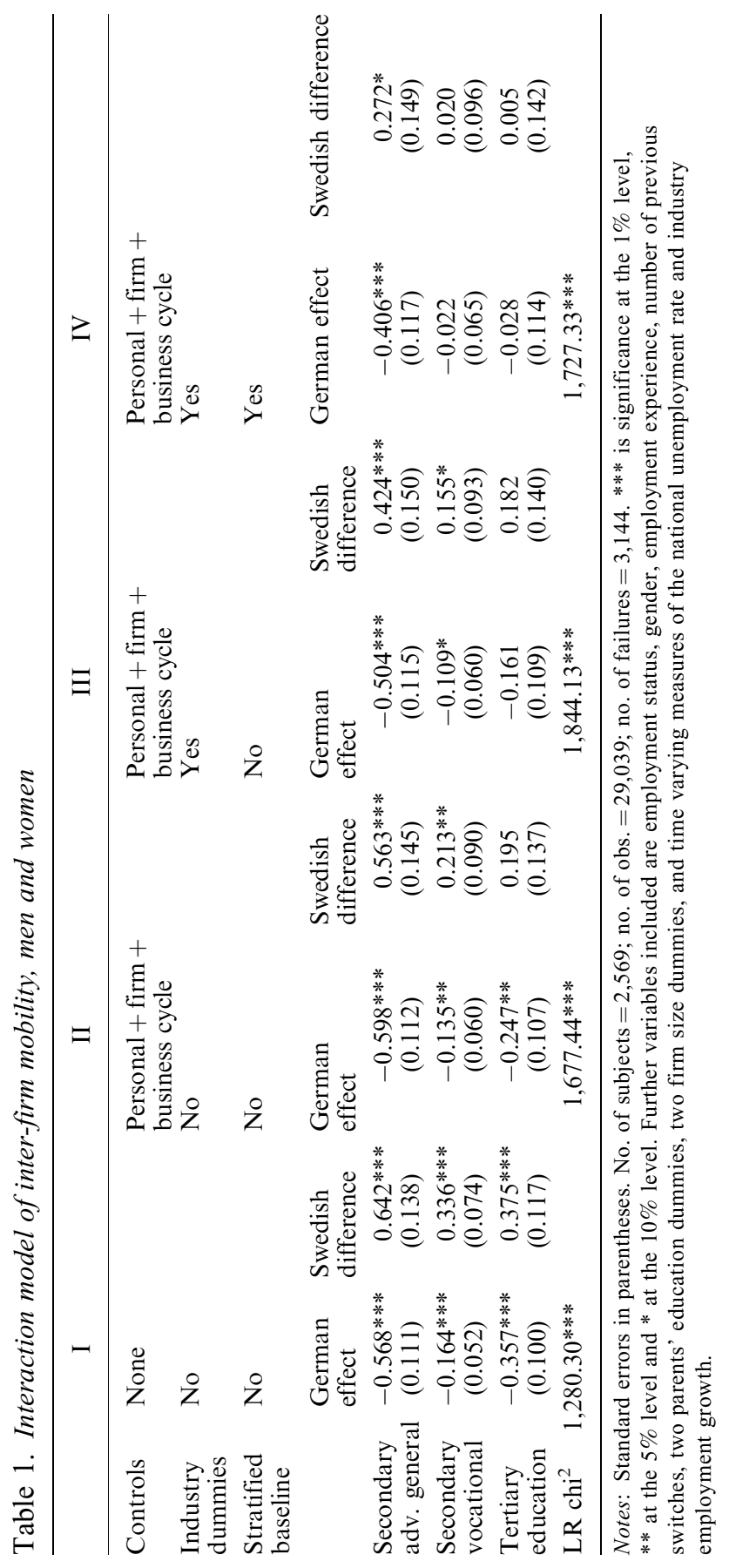

(C) The editors of the Scandinavian Journal of Economics 2003. 
Inter-occupational mobility is examined in Table 2. Model I again shows the basic differences in mobility among the educational groups. Among the German students those with vocational training or advanced upper secondary degrees make up a middle category, with university graduates clearly the least mobile. All Swedish groups are again more mobile than their German counterparts and, as in Germany, the least mobile Swedish group appears to be the university graduates.

The addition of control variables in Models II and III has only a limited impact on the educational effects. The differences within each country are somewhat diminished, and the gap between university graduates in the two countries disappears. The consequences of introducing country-specific baseline hazards in Model IV are instead of greater interest. There are now only slight indications of differences between the advanced upper secondary students. Moreover, the only Swedish category that now has a significantly higher transition rate than the corresponding German group consists of those with a vocational education.

These results are also depicted graphically in Figures 1 and 2. In terms of the baseline survivor functions for a representative individual, ${ }^{16}$ the difference between occupational and firm mobility becomes evident. The occupational survivor function of vocationally trained workers in Germany lies well above the Swedish curve, indicating that for all durations, German workers are more likely to stay within their occupation. For firm switches, the difference is minimal.

The results pertaining to inter-industry mobility are reported in Table 3. Starting with Model I, we recognize a by now familiar pattern. There are again rather marked differences in mobility among the German educational groups, with the university educated now the least mobile. The differences between the German and Swedish educational effects are all significant, and the differences in Sweden are smaller than in Germany. The addition of the personal, firm and business cycle variables in Model II again reduces the educational effects, and also eliminates the gap between the university graduates. However, the introduction of separate baseline hazards in Model IV removes the remaining distinctions as well.

To summarize, the initial analyses all show marked differences in mobility among the different educational categories in Germany and Sweden, including the apprentices and vocational school students. For those with advanced upper secondary and vocational degrees, these inter-country differences also tend to remain after personal, firm, industrial and business

\footnotetext{
${ }^{16}$ The representative individual is a male worker with vocational education who has one year of labor-market experience, no previous switches, works in a small firm and has parents with only basic vocational education. Macro and industry variables are considered at their mean values.
} 


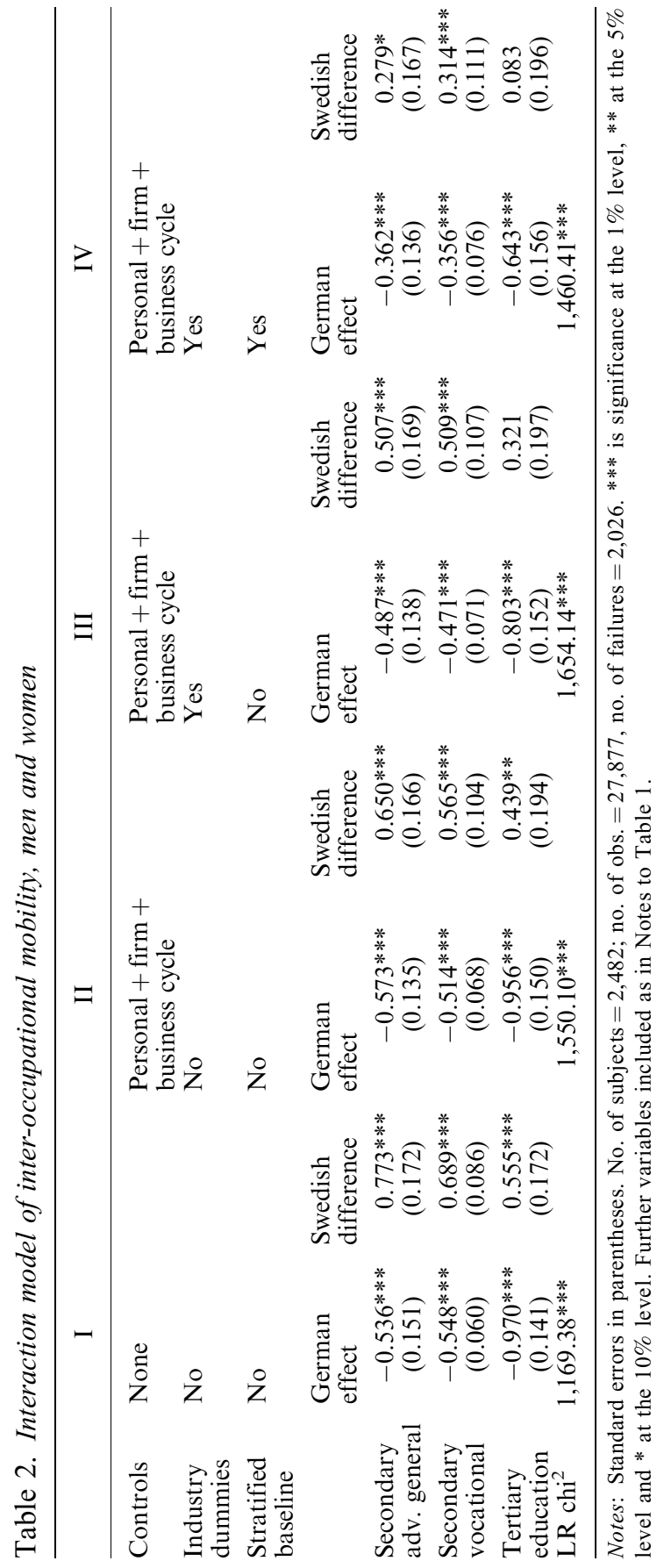

(C) The editors of the Scandinavian Journal of Economics 2003. 


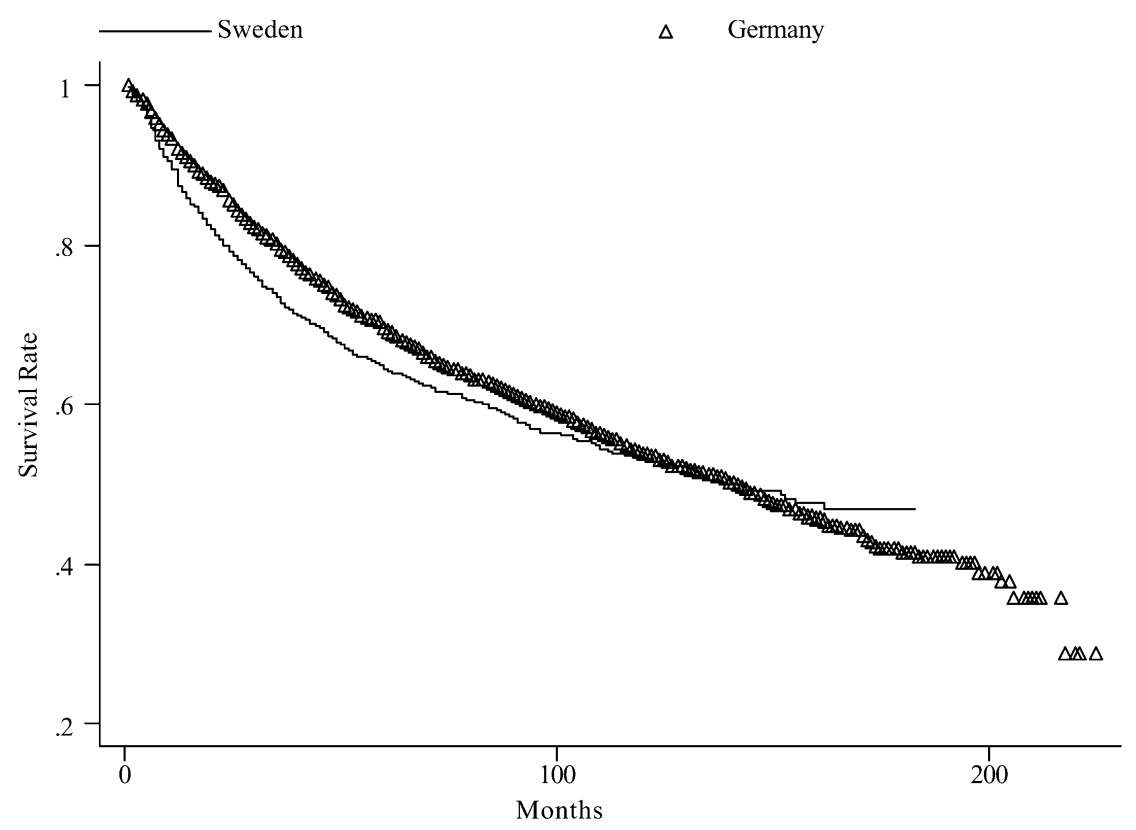

Fig. 1. Firm switches: baseline survivor functions for representative individuals

Note: The reference person has one year of experience, vocational training, works in the metal industry in a large firm and has parents with lower secondary education. Unemployment and industry employment growth are evaluated at the mean.

cycle factors have been taken into account. That the inter-country differences persist within both educational categories makes it less likely that the vocational difference is due to the structural aspects of the training systems. However, in the case of inter-firm and inter-industrial mobility, all remaining educational differences, including that related to vocational training, disappear once country-specific fixed effects are taken into account, i.e., once the country-specific baseline hazards are introduced. The only instance where a difference related to vocational training prevails, that is the only analysis where this result is independent of model specification, is in the case of inter-occupational mobility. ${ }^{17}$

\footnotetext{
${ }^{17}$ In addition to the alternative models mentioned in footnote 12 , we extended the analyses in two directions. First, we estimated separate models for men and women. Second, we examined differences in educational effects over working life by estimating separate models for each consecutive job. These analyses show occupational differences to be more pronounced among women than among men, but otherwise confirm the results in Tables 1-3. They are therefore not reported here, but may be obtained from the authors on request.
} 


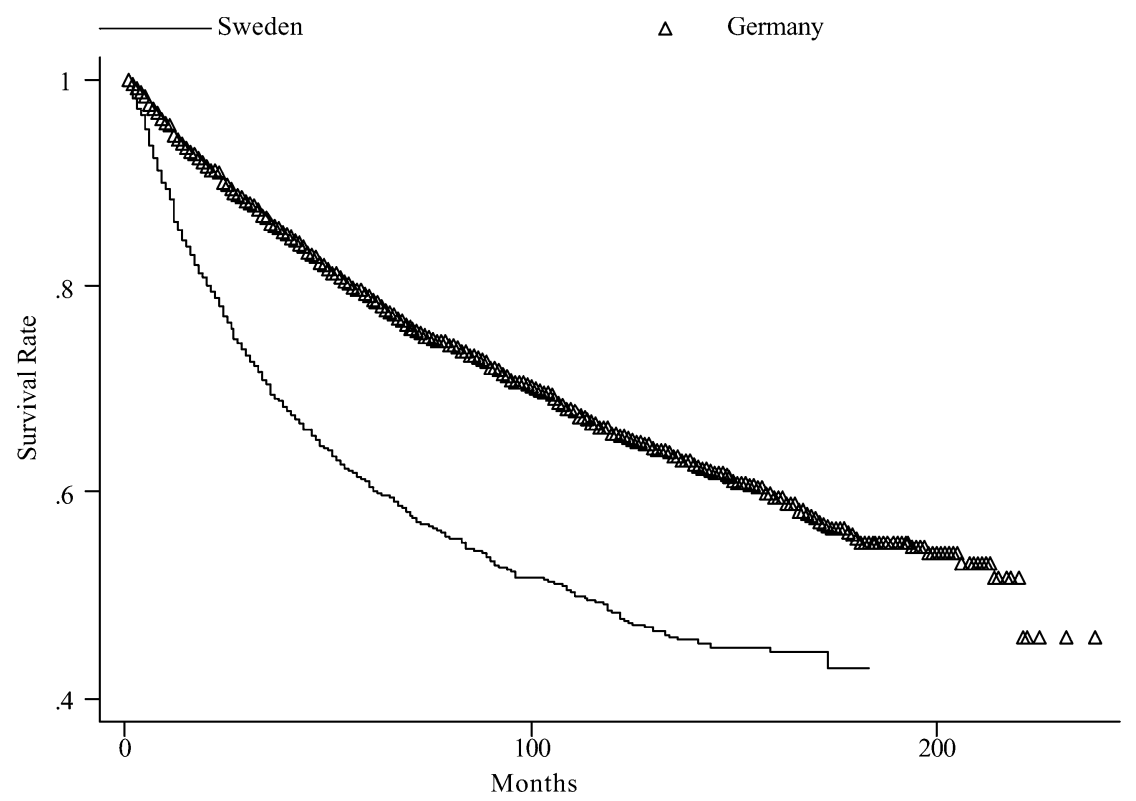

Fig. 2. Occupational switches: baseline survivor functions for representative individuals

Note: The reference person has one year of experience, vocational training, works in the metal industry in a large firm and has parents with lower secondary education. Unemployment and industry employment growth are evaluated at the mean.

\section{Summary and Conclusions}

The impact of vocational training on labor-market mobility is an important issue in the discussion of human capital as well as the design of educational systems. Our comparison of apprenticeship-based vocational training in Germany and school-based training in Sweden shows, first of all, that overall mobility rates not attributable to any measurable covariate are higher in Sweden than in Germany.

As regards mobility patterns, we find no differences in inter-firm mobility that can clearly be related to the type of vocational training. This suggests that the proportion of truly firm-specific skills acquired during a German apprenticeship is rather low in relation to the transferable skills obtained. It also implies that there is little evidence for one of the purported advantages of an apprenticeship system as compared to a system with school-based vocational training: it does not eliminate unnecessary and detrimental job shopping during the early stages of a worker's career and does not simplify labor-market entrance.

On the other hand, our results on inter-occupational mobility suggest that the German labor market is indeed more structured around training occupations 


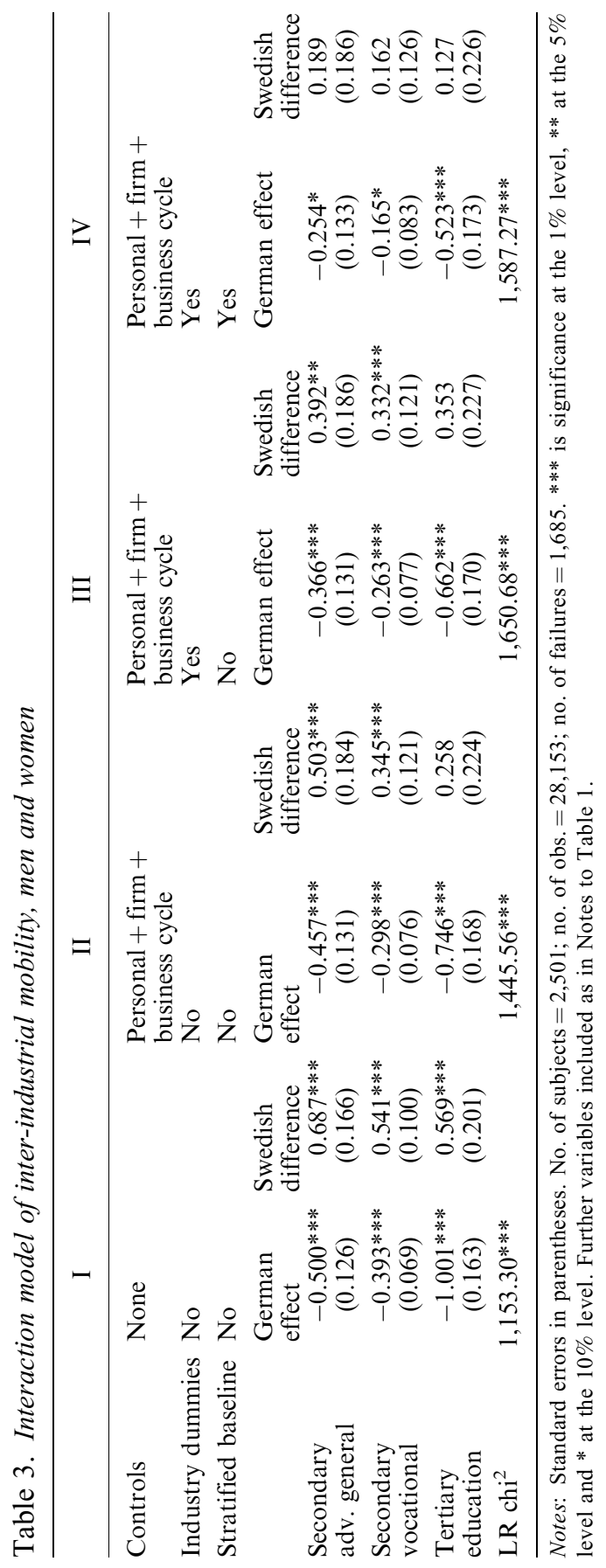

(C) The editors of the Scandinavian Journal of Economics 2003. 
than in Sweden where vocational training is school based. We observe lower inter-occupational mobility among apprentices, indicating that the skills obtained are less general than those gained through vocational school. This would seem to contradict claims that completion of an apprenticeship is a signaling device of worker quality rather than of occupational skill acquisition; see Heckman (1994) and Heckman, Roselius and Smith (1994). If individual careers require occupational mobility, this is undoubtedly disadvantageous. Negative side effects can also be expected if occupational flexibility is a necessary component of structural change. On the other hand, both educational systems seem equally conducive to industrial relocation, as we did not find any country differences in inter-industrial mobility. We therefore conclude that although it would appear to reduce occupational flexibility over an individual's work career, in terms of economic adjustment, the choice between vocational training systems would seem rather inconsequential.

\section{Appendix}

Table A1. Independent variables and descriptive statistics

\begin{tabular}{|c|c|c|c|}
\hline Variable & Definition & Mean & Std. dev. \\
\hline $\begin{array}{l}\text { Elementary }+ \text { lower } \\
\text { secondary general }\end{array}$ & $\begin{array}{l}\text { Compulsory and lower level sec. } \\
\text { schooling (Haputschule, Realschule, } \\
\text { Grundskola, or two years non-vocational } \\
\text { Gymnasium) }\end{array}$ & 0.22 & 0.41 \\
\hline $\begin{array}{l}\text { Secondary vocational } \\
\text { school }\end{array}$ & $\begin{array}{l}\text { Sec. level voc. training, school-based } \\
\text { degree (Berufsfachschule or voc. Gymnasium) }\end{array}$ & 0.10 & 0.30 \\
\hline $\begin{array}{l}\text { Secondary voc. } \\
\text { apprentice }\end{array}$ & $\begin{array}{l}\text { Sec. level vocational training, } \\
\text { apprenticeship degree (Lehre) }\end{array}$ & 0.47 & 0.50 \\
\hline $\begin{array}{l}\text { Secondary advanced } \\
\text { general }\end{array}$ & $\begin{array}{l}\text { Full maturation degree (Abitur } \\
\text { or 3-4 years non-vocational Gymnasium) }\end{array}$ & 0.07 & 0.26 \\
\hline Tertiary & $\begin{array}{l}\text { Tertiary level degree (Fachhochschule } \\
\text { or university) }\end{array}$ & 0.13 & 0.34 \\
\hline Sex & Wom & 0.46 & 0.50 \\
\hline $\begin{array}{l}\text { Employment } \\
\text { experience }\end{array}$ & $\begin{array}{l}\text { Employment experience at } \\
\text { start of spell (months) }\end{array}$ & 29.93 & 54.97 \\
\hline $\begin{array}{l}\text { No. of previous } \\
\text { switches }\end{array}$ & $\begin{array}{l}\text { Number of firm, occupational or } \\
\text { industry switches at start of spell }\end{array}$ & 0.69 & 1.12 \\
\hline $\begin{array}{l}\text { Parents' education- } \\
\text { basic }\end{array}$ & $\begin{array}{l}\text { Highest educational qualification } \\
\text { of parents, compulsory }\end{array}$ & 0.26 & 0.44 \\
\hline $\begin{array}{l}\text { Parents' education- } \\
\text { lower secondary }\end{array}$ & $\begin{array}{l}\text { Highest educational qualification } \\
\text { of parents, lower secondary }\end{array}$ & 0.63 & 0.48 \\
\hline $\begin{array}{l}\text { Parents' education- } \\
\text { higher secondary }\end{array}$ & $\begin{array}{l}\text { Highest educational qualification } \\
\text { of parents, higher secondary or above }\end{array}$ & 0.11 & 0.31 \\
\hline Firm s & less than 20 & 0.47 & 0.50 \\
\hline - medium & $\begin{array}{l}\text { No. of employees greater than or } \\
\text { equal to } 20 \text { and less than } 500\end{array}$ & 0.38 & 0.48 \\
\hline Firm size-large & $\begin{array}{l}\text { No. of employees greater than } \\
\text { or equal to } 500\end{array}$ & 0.16 & 0.3 \\
\hline
\end{tabular}




\begin{tabular}{llll} 
Not employed* & $\begin{array}{l}\text { = } 1 \text { if not employed, } \\
\text { 0 if employed (modeled time-varying) }\end{array}$ & 0.16 & 0.36 \\
$\begin{array}{l}\text { Unemployment rate* } \\
\text { National yearly unemployment } \\
\text { rate (modeled time-varying) }\end{array}$ & 4.11 & 1.98 \\
$\begin{array}{l}\text { Industrial growth rate* National yearly employment growth } \\
\text { rate in industry of empl. (modeled } \\
\text { time-varying) }\end{array}$ & 0.46 & 2.88 \\
\hline
\end{tabular}

Note: All statistics based on spells $(n=5,910)$, except for $*$ which are based on subspells $(n=27,877)$.

\section{References}

Acemoglu, D. (1997), Training and Innovation in an Imperfect Labor Market, Review of Economic Studies 64, 445-446.

Acemoglu, D. and Pischke, J.-S. (1998), Why do Firms Train? Theory and Evidence, Quarterly Journal of Economics 113, 79-119.

Acemoglu, D. and Pischke, J.-S. (1999a), Beyond Becker: Training in Imperfect Labour Markets, Economic Journal 109, F112-F142.

Acemoglu, D. and Pischke, J.-S. (1999b), The Structure of Wages and Investment in General Training, Journal of Political Economy 107, 539-572.

Baily, M., Burtless, G. and Litan, R. E. (1993), Growth with Equity: Economic Policymaking for the Next Century. Brookings Institution Press, Washington, DC.

Becker, G. S. (1964), Human Capital: A Theoretical and Empirical Analysis with Special Reference to Education, Columbia University Press for National Bureau of Economic Research, New York.

Booth, A. and Satchell, S. (1995), On Apprenticeship Qualifications and Labour Mobility, in A. Booth and D. Snower (eds.), Acquiring Skills: Market Failures, their Symptoms and Policy Responses, Cambridge University Press, Cambridge.

Borghans, L., de Grip, A. and Smits, W. (1995), Labour Market Mobility of Technically Educated Persons, manuscript, Research Centre for Education and the Labour Market, Maastricht.

Brückner, E. and Mayer, K. U. (1998), Collecting Life History Data-Experiences from the German Life History Study, in J. Z. Giele and G. H. Elder Jr. (eds.), Methods of Life Course Research: Qualitative and Quantitative Approaches, Sage, Thousand Oaks, CA.

Burda, M. and Mertens, A. (2001), Estimating Wage Losses of Displaced Workers in Germany, Labour Economics 8, 15-41.

Di Prete, T. A., de Graaf, P. M.,Luijkx, R., Tåhlin, M. and Blossfeld, H.-P. (1997), Collectivist versus Individualist Mobility Regimes? Structural Change and Job Mobility in Four Countries, American Journal of Sociology 103, 318-358.

Euwals, R. and Winkelmann, R. (2001), Why Do Firms Train? Empirical Evidence on the First Labour Market Outcomes of Graduated Apprentices, Discussion Paper no. 319, IZA, Bonn.

Farber, H. S. (1994), The Analysis of Interfirm Worker Mobility, Journal of Labor Economics 12, 554-593.

Franz, W. and Soskice, D. (1995), The German Apprenticeship System, in F. Buttler, W. Franz, R. Schettkat and D. Soskice (eds.), Institutional Frameworks and Labor Market Performance, Routledge, London.

Franz, W. and Zimmermann, V. (1999), Mobilität nach der beruflichen Erstausbildung: Eine empirische Studie für Westdeutschland, Jahrbücher für Nationalökonomie und Statistik 219, $143-164$.

Harhoff, D. and Kane, T. J. (1997), Is the German Apprenticeship System a Panacea for the U.S. Labor Market?, Journal of Population Economics 10, 171-196.

(C) The editors of the Scandinavian Journal of Economics 2003. 
Hashimoto, M. (1981), Firm-specific Human Capital as a Shared Investment, American Economic Review 71, 475-482.

Heckman, J. (1994), Is Job Training Oversold?, Public Interest 115, 91-115.

Heckman, J., Roselius, R. L. and Smith, J. A. (1994), U.S. Education and Training Policy: A Re-evaluation of the Underlying Assumptions behind the New Consensus, in L. C. Solmon and A. R. Levenson (eds.), Labor Markets, Employment Policy and Job Creation, Westview Press, Boulder, CO.

Hofbauer, H. and Nagel, E. (1987), Mobilität nach Abschluß der betrieblichen Ausbildung, Mitteilungen aus der Arbeitsmarkt- und Berufsforschung 1/87, 45-73.

Jonsson, J. O. and Mills, C. (2001), Cradle to Grave. Life-course Changes in Modern Sweden, Sociology Press, Durham, UK.

Loewenstein, M. A. and Spletzer, J. R. (1999), Dividing the Costs and Returns to General Training, Journal of Labor Economics 16, 142-171.

Mertens, A. (1998), Labor Mobility and Wage Dynamics-An Empirical Study for Germany in Comparison with the United States, Shaker Verlag, Aachen.

Neal, D. (1995), Industry-specific Human Capital: Evidence from Displaced Workers, Journal of Labor Economics 13, 653-677.

Schober-Brinkmann, K. and Wadensjö, E. (1991), Contrasting Forms of Youth Training and Employment in Sweden and FR Germany, in P. Ryan, P. Garonna R. Edwards (eds.), The Problem of Youth: The Regulation of Youth Employment and Training in Advanced Economies, Macmillan, London.

Soskice, D. (1994), Reconciling Markets and Institutions: The German Apprenticeship System, in L. M. Lynch (ed.), Training and the Private Sector-International Comparisons, University of Chicago Press, Chicago and London.

SOU (1986), En treairig yrkesutbildning. Del 1, Riktlinjer för fortsatt arbete (Three-year Vocational Training-Part 1, guidelines for Further Work). SOU 1986:2, Ministry of Education, Stockholm.

Spence, M. (1973), Job Market Signaling, Quarterly Journal of Economics 87, 355-374.

Statistics Sweden (1988), Yearbook of Educational Statistics 1988, Stockholm.

Steedman, H. (1993), The Economics of Youth Training in Germany, Economic Journal 103, 1279-1291.

Stern, D., Finkelstein, N.,Stone III, J. R., Latting, J. and Dornsife, C. (1995), School to Work: Research on Programs in the United States, Falmer Press, Washington, DC.

Stevens, M. (1994), A Theoretical Model of On-the-job Training with Imperfect Competition, Oxford Economic Papers 46, 537-562.

Thurow, L. (1992), Head to Head: The Coming Economic Battle among Japan, Europe, and America, Morrow, New York.

Topel, R. H. and Ward, M. P. (1992), Job Mobility and the Careers of Young Men, Quarterly Journal of Economics 107, 445-479.

Wagner, K. (1999), The German Apprenticeship System under Strain, in P. Culpepper and D. Finegold (eds.), The German Skill Machine: Sustaining Comparative Advantage in a Global Economy. Berghahn Books, New York.

Werwatz, A. (1997), Mobility after Apprenticeship-How Effective is the German Apprenticeship System?, Discussion Paper no 1997-75, Sonderforschungsbereich 373, Humboldt University Berlin.

Winkelmann, R. (1996a), Employment Prospects and Skill Acquisition of Apprenticeshiptrained Workers in Germany, Industrial and Labor Relations Review 49, 658-672.

Winkelmann, R. (1996b), Training, Earnings and Mobility in Germany, Konjunkturpolitik 42, 275-298.

First version submitted January 2002;

final version received January 2003. 
